Сања Ж. Ђуровић

Универзитет у Крагујевцу

Филолошко-уметнички факултет

https://doi.org/10.18485/ai_beckovic.2019.ch13

821.163.41.09-1 Бећковић М.

811.163.41'373

\title{
СТИЛЕМАТИЧНА ЛЕКСИКА У ИЗАБРАНИМ ПОЕМАМА М. БЕЋКОВИЋА**
}

$\mathrm{y}$ раду се на примерима издвојених стилематичних лексема из треће књиге поема Леле и куку (Лелек мене и Вучја тужбалииа) анализира граматички, семантички и творбени статус лексема и указује на богатство језичког израза М. Бећковића.

Клучне речи: лексема, семантика, творба речи, поема, Матија Бећковић

1. О поезији Матије Бећковића доста је писано и сви су сагласни да Бећковић специфично употребљава језик и да језик код њега има важну улогу. У бројним радовима разматрана су различита питања у вези са Бећковићевом поетиком који ће нам посредно послужити у анализи.

Предмет рада биће стилематична лексика у изабраним поемама из књиге Леле и куку (Лелек мене и Вучја тужбалииа $)^{1}$. У Белешкама уз поеме Бећковић каже:

\footnotetext{
* sdjurovic74@gmail.com; sanja.djurovic@filum.kg.ac.rs

** Рад је урађен у оквиру пројекта 178014: Динамика структура савременог српског језика, који финансира Министарство просвете, науке и технолошког развоја Републике Србије. Коришћена је књига Поеме у издању Српске књижевне задруге, књ. 508, 1983.
} 
„Леле и куку је епилог књига Рече ми један чоек и Међа Вука Манитога. То је био пут од чисте лексике и голих минерала језика до њиховог подразумевања и превазилажења. Пут од слепог камења, једнооких погледа и једноумних схватања - до апстрактног мишљења и „првог камена који се није вратио” (Бећковић 1983: 345).

Циљ рада биће анализа граматичког, творбеног и семантичког статуса издвојених лексема и указивање на њихову функцију у тексту. „Под стилематичном лексиком подразумијевамо стилски маркирану лексику, лексику што се може подвести под стилеме као минималне јединице стилског појачања. Стилематичност стилеме препознаје се или у структурном (формалном) или у семантичком (значењском) онеобичајењу неке лексичке јединице. Да би нека лексема била препозната као стилематична, она мора изневјерити или своју основну (општеупотребну) форму или своје основно (узуално) значење" (Ковачевић 2013: 244).

Лексичко богатство Бећковићевог језика је изразито, песник експериментише, удружује речи, спаја и комбинује користећи продуктивне творбене моделе и прави бројне необичне лексеме, те није случајно што се у литератури истиче да му је „творење у језику приоритет” (Радуловић 1999로 597).

„Језику Бећковићевих поема суоднос дијалекатских и стандарднојезичких особина прибавља статус стилистички врло обиљеженог, тј. стилематичног. Бећковић је тако већ самим избором органског идиома повећао стилистички потенцијал свога израза. Из тих се разлога и Бећковићев језик у поемама, макар и био потпуно подударан са ровачким говором мора прихватити као изразито стилематичан. На општем нивоу дијалекатске особине перципирају се као свјесне интервенције у структури стандардног језика, што произведеном тексту - посматраном из наметнуте перспективе стандардног језика - прибавља статус онеобичајеног" (Ковачевић 1995: 105). 
У књизи Поеме налази се и Речник мане познатих речи Д. Петровића ${ }^{1}$ што сведочи о бројним лексичким творевинама писца. Велики број ексцерпиране лексике је забележен у речнику и то нам је олакшало семантичку и творбену анализу, али део лексике остао је изван речника и ту нам је ослонац био контекст и језичко осећање.

2. Анализа корпуса спроведена је тако што је сва екцерпирана лексика класификована према творбеном статусу (просте, изведене, сложене, префиксалне творенице, примери комбиноване творбе) и према врстама речи, а онда се даје семантичка анализа појединачних лексема или читаве класе. Показало се да је сва ексцерпирана стилематична лексика већином из класе именица и ређе из класе придева. Понеки придеви су стилски маркирани, али су ретки (нпр. коротне 2 капе, льуцке душе, љуизке вјере). Код глагола нема изразите стилематичности сем што се примећује употреба окрњеног инфинитива и то због метрике, очувања десетерца (нпр. муиат, побиједит, радоват се, сагнут се и сл.). Све издвојене лексеме могли бисмо окарактерисати као неологизме или оказионализме.

2.1. Просте именице које припадају стилематичној лексици у изабраном корпусу су ретке. Јављају се само три и све су забележене и у Речнику уз поеме што нам је олакшало семантичку анализу.

корота (321); мобиље (298); чонта (321).

У РДП уз именицу мобиље стоји 'намештај, покретна имовина'. Чонта је 'чеона жила, која у љутини набрекне,' а корота је 'жалост, црнина'.

1 У даљем тексту РДП.

2 У РДП корота је жалост, црнина, па је тако изведени придев коротан - жалостан, црн. 
2. 2. Деривати су најбројнији у корпусу. Забележени су само именички деривати (укупно 44). Творбено-семантичка анализа била је олакшана тиме што је у РДП забележена већина ових лексема.

бивак (300); бињикташ ${ }^{3}$ (331); букалице (321); вукарење (337); гробак (326); гробић (330); гробурак (328); гробишта (325); достина (308); задуженици (321); звиринак (323); ивинак (324); изворник (313); кућићи без кућа (300); колеж ${ }^{5}(325)$; крбурани ${ }^{6}(321)$; крварина (317); људурина (300); мишаре и мегаре (299); мнозина (308); мрзија (331); мрчава (298); натока (299); окомак ${ }^{7}$ (325); планинштаци (321); превратиште, поклониште и побијалиште (317); поносници (321); првина (297); проник (331); пуклина (318); путљаг (330); ридник (331); сложиште (329); сретњикање (305); стопаник (299); тоциљаш (335); ћаскалице (321); ћошник ${ }^{8}$ (323); цуњала (321); чапорак ${ }^{9}$ (331); шеганица ${ }^{10}(326)$.

У РДП налазимо значење за следеће лексеме: ивинак је 'танка ивица'; мишара је 'кућица која личи на мишју рупу' Творбени модел је миш-ара. Мегара је 'примитивно склепана кућица'. Очито је творбени модел мег-ара, али је мотивна реч у творбеној основи непрозирна. Натока је оно 'што се постепено натаче, налива соковима'. Творбени образац је нато-ка, окрњена глаголска основа од

3 У РДП бињикташ је 'камен са кога се узјахује на коња'. Према биґик - скакање, јурњава.

4 Синтагматски оформљени оксиморон (Ковачевић 1995: 109).

5 У РДП колеж је 'кукњава, плач'.

6 У РДП крбуран - човек грубог изгледа. Изведена је именица од именице крбура (жлеб од букове коре; трула буква) + суфикс -ан.

7 У РДП окомак је 'врх окомите стене'.

8 У РДП ћошник је 'угаони камен, угао, ћошак'.

9 У РДП чапорак - 'окресак, део гране који је приликом окресивања остао на стаблу'.

10 У РСД шеганица је 'пиљена даска (насупрот тесаној)'. 
наточити и суфикс -ка. Првина је 'претходница' (првuна). Аугментатив вудурина има пејоративно значење управо због суфикса -урина. Стопаник - у значењу путельк, постопииа, пртина; превратиште - 'место на коме се дешавају чести преокрети, преврати'. Творбени образац био би стоп-аник. Од глагола у творбеној основи (од ћаскати и букати (правити буку)) на које је додат суфикс -ица настале су именице: ћаскалица, букалица, од глагола цуюати именица цуюало (цуња-ло). Од прилога доста у творбеној основи изведена је именица достина. У РДП стоји достина -е ж 'мнозина'. Звиринак је 'пукотина, рупица кроз коју се може вирити као кроз распуклу даску'. У творбеној основи је глагол звирити ${ }^{11}$. Ридник је 'велики камен, камена плоча'. У творбеној основи је именице рида (у значењу каменчина) на коју је додат суфикс -ник. Проник је 'ницање усева, никло'. Настала је као поствербал од глагола проникнути, одбијањем наставка -нути (проник-ø). Необична је формулација значења именице мрзија у РДП - 'стара мржња, чији разлози више нису увек јасни'. Мржња се не може класификовати на стару и нову, нарочито не у примарном значењу. Творбена мотивација је прозирна: основа гл. мрзети и суфикс-ија.

Мрчава ${ }^{12}$ није забележена у РДП, али јесте мрч ('гар, чађ'). Изразиту експресивност имају именице бивак и крварина које, такође, не бележи РДП. Бивак је према бивати +-ак, а крварина по моделу крв-арина вероватно у значењу 'место где се плаћа крвљу' (по моделу путарина). Планинштаци је настало вероватно према моделу горитаци.

Јавља се неколико деминутива именице гроб - гробак, гробић, гробурак и именица са значењем места гробиште. Све именице су стилски маркиране. Месно

11 У РМС звирити, -им несврш. покр. вирити.

12 А навиљак држгоре - мрчава! (298). 
значење имају и деривати превратиште, поклониште и побијалиште са прозирном мотивацијом - место где се дешава преврат, место где се поклања, клања и оказионална лексема побијалиште - место где се налазе побијени. У корпусу су и две глаголске именице: сретникање која је потврђена у РДП у значењу 'честитање, честитка' и вукарење која није забележена у РДП, али је јасно изведена преко глагола вукарити ${ }^{13}$.

2. 3. Сложенице су веома стилогене и представљају песникову креативност у језику. Ексцерпирано је укупно 35 сложених именица, али у корпусу их има и више, пошто смо сложена властита имена анализирали у посебном одељку. У закључку ћемо представити све резултате обједињено како бисмо јасно указали на богатство Бећковићевог језика.

\section{а) Именичке сложенице}

бољиглава (299); бољоглава (316); гробоносац (326); грободер (336); вртивода (302); вуковлак (331); вукозора (337); вукоборац (337); вукорог (338); вукодол (338); вуколист (338); вукољуд (339); вучивуна (336); вучивода (336); вучидлака (336); вучистрах (337); држгора (298); дубирог (300); једноумци (321); котловар (302); куковук (324); крстолом (336); лажицаре (312); љутидрач (329); миљоказа (335); мрдочели (321); преливоде (321); самоков (335); саморанац (326); самотвор (323); самосад (323); самораст (323); сувомеђа (329); туцибраћа (308); узмидух (336).

У РДП држгора је 'ситно растиње по каменитој голети'. Творбени образац држ-гора (држати и гора). Бољоглава је настала као резултат песниковог поигравања и ту пре-

13 У РМС вукарити, -им несврш. покр. вући, вуцарати, носити дуго (нпр. одело). 
познајемо инверзију унутар лексеме главобоља. Јавља се и варијанта бољиглава. По моделу императивних сложеница настале су лексеме вртивода, вучивода и преливода према уобичајеном мутивода. Истог типа су и лажииаре, туиибраћа, узмидух. Дубирог је 'колиба купастог облика, савардак'. Котловар је у РДП 'водени ковитлац, вир, коловрат.' Чини се као да је песник испремештао ред слова из речи коловрат и направио котловар. Лексема мрдочели (у тексту употребљена у множини) није забележена у РДП, али они који гестикулирају померањем чела су мрд-о-чели (гл. мрдати + -о- + чело). Истомишљеници су једн-о-умии. Творбено се може сматрати и примером сложено-суфиксалне творбе пошто умизи не постоји као самостална лексема. Куковук је 'место на коме ће и вука подићи језа, где ће и вук закукати, почети да завија'. Творбени модел: кук-о-вук (у првом делу сложенице окрњена гл. основа глагола кукати).Са творбеном основом вук-/ вуч- јавља се 11 лексема и једна лексема са вук у другом делу творенице (куковук).

\section{б) Придевске сложениц}

српокрилим, првим ријечима (297); прволиком, невином првином (297); кезизуба небраћа (321).

Сложених придева је много мање, забележена су само три. У РДП нису забележени. Два су настала слагањем помоћу спојног вокала, а један је пример императивне сложенице (срп-о-крили, -а, -о; прв-о-лик, -а, -о; кезизуб,-а,-о). У Вучјој тужбалици забележени су низови сложених придева, али не припадају стилогеној лексици, већ су значајнији за стилистичку анализу и за метрику.

2.4. Префиксалне и префиксално-суфиксалне творенице (укупно 33) најчешће су оказионализми и припадају класи именица. 
безродице (313); бездомице (313); бродоломник (301); вукотвор (335); вуколом (337); вукујед (337); вуцидер (337); вукозов (337); гороломник (300); горостасник (300); дивногорци (300); дожудник (332); измирник (332); исклонак (325); костождер (336); наокрс (332); несој (307); нуглокам (324); одљуди (321); подљуди (321); поземљуше (300); поткожници (321); постељоиздавци (321); подворници (321); подајници (321); потпорник (335); превјерице (321); презид (324); подрепнице $\mathrm{e}^{14}$ (321); подложници (321); посијеч (297); процмиљка (323); раскућа (319).

По моделу вук-/вуку- + окрњена глаголска основа настале су именице типа вук-о-творо-зов-, вуку-јед- . По сличном моделу настала је и именица кост-о-ждер-ø. Значења ових лексема нису наведена у РСД. Човек лошег порекла, соја је несој (не-сој). Нуглокам је угаони камен, ћошник. Исклонак је 'место са кога се, после успона уз брдо, отварају нови видици, видиковац. У РСД бележи се значење именице проимиљак - 'зрачак сунца који се пробије кроз густо грање', а по творбеном моделу про-цмиљ-ак (у творбеној основи је лексема имиље (смиље)). Онај који издаје постељу је постељьоздаваи (постељ-о-издав-ац). РСД не бележи ову именицу.

2.5. У посебну групу издвојили смо лексеме које су настале непродуктивним моделима творбе и представљају пишчево поигравање и комбиновање различитих спојева, док у резултату имамо најчешће оказионализме.

засебници (304); јапајајци (321); немаништеници (321); неботици (305); празнозбори (321); придворице (321).

14 У РДП подрепница је „1. део коњске опреме, каиш који се са самара пружа испод репа и 2. човек који се може упрегнути у сваки нечастан посао". 
Ове лексеме нису посведочене у РДП. Засебници су они који су само за себе. Од предлошко-падежне синтагме (за себе) направљена је префиксално-суфиксална твореница. Неботици су они који стреме ка небу. Значење се јасно уочава из контекста. Они који стално говоре „ја па ја” биће јапајајиц. Овакви модели творбе бележе се у литератури као примери специфичне творбе оказионализама типа алисати (стално понављати али) и сл. Они који 'немају ништа' су немаништенищи, а који 'празно зборе' (говоре) су празнозбори.

2.6. Посебно смо издвојили делове поеме Лелек мене где се јасно уочава низање стихова који су саткани од стилематичне лексике, а што је значајно у сагледавању функције ових лексема, али и јасног пишчевог „рада” на лексемема.

„Све је у њој једно и једито,

Једнопоно, цијелац, унина,

Препунано смоле и натоке.

Ту множине никад није било!" (299);

У РДП издвојене су лексеме једити, -a, -о (адј. 'један, једини, јединцати'), једнопон, -a, -о (адј. 'целовит, из једног комада, без шавова и спојева'), иијелаи ('1. неугажен снег; 2. што је сачувано, недирнуто целовито') и унина ('јединственост, целовитост').

Најупечатљивији део поеме Лелек мене у коме се нижу једна за другом стилематичне лексеме, где се писац трудио да прави и гомила бројне неологизме, при чему се понављају одређени вокали и консонанти (асонанца и алитерација) јесу следећи стихови:

„Да нас не би, свијет не би знао,

Да постоје горди конобари, 
Подворници с хајдучким брцима,

Подајници с чонтом међу очи,

Превјерице с коротним капама,

Преливоде с дигнутим главама,

Подрепнице усавардачене,

Поносници постељоиздавци,

Планинштаци смрштени ласкавци,

Подложници гласни јапајајци,

Поткожници с крупнијем грлима,

Празнозбори и немаништеници,

Крбурани с глатким ријечима,

Придворице које подмигују,

Испршени кицоши што просе,

Обретници и покајаници,

Једноумци и задуженици,

Букалице тморе ћаскалице,

Набурена космата цуњала,

Издајници у народној ношњи,

Нејакима не дају преда се,

Пред јакима се главом пода се,

Мрдочели припузни подљуди,

Кезизуба небраћа, одљуди,

Уз гусле ће молбу поднијети,

Двострук оро ко чочек играти,

Ђецу вјешат а власт поштивати,

Молећи се Богу дволичати,

Лелечући нешто шићарити!"(321).

У претходном делу анализе појединачних лексема анализиране су и лексеме из овог одељка, али је било важно представити како су оне уклопљене и у контексту како би се боље сагледала њихова формална и семантичка функција у тексту која оставља простора и за стилистичку анализу.

У Вучјој тужбалици писац ниже именице и придеве сличних творбених основа и сличног сазвучја правећи тако интонацију тужбалице. Појединачне именичке лексеме су анализиране у оквиру творбено-семантичке 
анализе, али важно је указати и на њихову функцију у тексту и редослед појављивања који није случајан. Ређају се именице самотвор, самосад, самораст, затим окуn, докуn, искуn, а затим и велики број придева који се јављају у низовима, а које нисмо анализирали појединачно јер нису део стилематичне лексике, али су итекако стилски маркирани и играју важну улогу за метрику поеме (нпр. дугачкога, шеганога, сјемечнога, зглобленога, крвавога, капалога, посутога, сувотнога, израслога (326); бабунскога, лужанскога, габетькога, мађупскога, чобанскога, сватовскога, морнарскога, хајдучкога, војничкога, монашкога, чивутскога, турскога (328) итд.).

2.7. Посебан део корпуса чине антропонимијске јединице (властита имена и презимена) са основом вук- из поеме Вучја тужбалиц, $a^{15}$ које су, такође, стилогеног карактера. Имена су већином дата у облику вокатива у поеми, али их наводимо у номинативу како бисмо јасно одредили творбену структуру и мотивацију имена. Сви антропоними су разврстани на две велике групе - имена и презимена, а онда унутар класе имена према творбеном критеријуму на проста, изведена и сложена.

\subsection{1 Имена}

Како се наводи у литератури ${ }^{16}$, Бећковић овде прави „вучју плетеницу” која је настала варирањем речи Вук. Издвојено је око триста антропонима, и то највише изведених (166), сложених (112) и простих (13). Поред основе вук- јавља се и основа ву-као и слагање са другим творбеним основама (маливук, световук и сл.).

15 „Вучја тужбалииа је дубоко интимни песнички родослов, али и родослов архетипова српске традиционалне културе. [...] Вук је лично име Бећковићеве поезије. Вучје легло његовог 'ровачког' трокњижја јесте језик испод камена” (Сувајџић 2012: 152-154).

16 Радуловић 1999: 598. 
а) проста имена - укупно 13 која се могу посматрати као проста, али и као изведена преко корена Вук- (нпр. Вуко, Вуча) или окрњеног облика Ву- (нпр. Вуиза, Вута, Byjo, Вуил и сл.). Ми смо их посматрали као просте именице пошто основа Ву- може бити и самостална, не мора се обавезујуће везивати са обликом Вук.

Вук, Вушо, Вуца, Вута, Вуча, Вуко, Вуле, Вуло, Вуша, Вуил, Вућа, Вуса, Вујо.

б) изведена имена

Вукалица, Вучко, Вуило, Вулан, Вујно, Вучела, Вукота, Вукешан, Вујадин, Вујаш, Вујанац, Вукућа, Вучја, Вујча, Вукава, Вукотин, Вујимио, Вукољ, Вукосим, Вукота, Вушко, Вукашин, Вукола, Вуиша, Вуин, Вуикан, Вукош, Вучајица, Вучакина, Вујат, Вујша, Вујан, Вујка, Вујица, Вукула, Вујош, Вукојло, Вукаило, Вукан, Вукадин, Вулета, Вукало, Вуколај, Вукан, Вујда, Вукавица, Вучило, Вучихна, Вукат, Вукац, Вукањело, Вујаклија, Вукаица, Вујчин, Вујачко, Вукиња, Вукоило, Вудро, Вусјо, Вујас, Вукаин, Вузеница, Вукачина, Вучељак, Вујкасин, Вукељача, Вукља, Вукија, Вусањанко, Вушин, Вусика, Вујкуша, Вукотица, Вуколица, Вукланац, Вукона, Вучичин, Вукињан, Вукета, Вућило, Вукишан, Вукиљан, Вукрпан, Вуичиле, Вучикан, Вулишан, Вукадун, Вухредин, Вукна, Вучурда, Вукоин, Вуичета, Вуцељин, Вукослов, Вулич, Вукентије, Вудраник, Вукошин, Вулекан, Вунишан, Вункован, Вујал, Вучица, Вуиско, Вујкуша, Вученко, Вученик, Вукрсије, Вујканика, Вучерина, Вучевина, Вукусав, Вуислав, Вучисав, Вукуља, Вукорија, Вучоња, Вукохна, Вучешина, Вујачин, Вујетан, Вулиша, Вујач, Вујасин, Вучијица, Вукочина, Вукина, Вућо, Вулаковој, Вујаковој, Вучина, Вуксан, Вушур, Вукица, Вучим, Вучијанац, Вуимиле, Вучоје, Вукела, Вујашин, Вучула, Вукољин, Вукаље, Вукаш, Вукша, Вучењак, Вуквоин, Вуинам, Вуцкан, Вукенија, Вукеза, Вуковија, Вуковије, Вуисав, Вукасица, Вукомаш, Вучијак, Вучета, Вуколина, Вулче, Вукорљава, Вуканчило, 
Вујко, Вукијан, Вулашин, Вукотинаш, Вукодије, Вучкулин,

Вукешара, Вучур, Вушан, Вукса, Вукој, Вујошин, Вукушица.

У корпусу је посведочено 165 изведених имена са творбеном основом Вук-/Ву-. Већина имена нису уобичајена властита имена, већ су стилски маркирана и представљају резултат песникове креативности (нпр. Вукуља, Вулаковој, Вудраник, Вучихна, Вусика и сл.). Уобичајена имена су Вујадин, Вукан, Вукадин, Вукша, Вучета, Вулета и сл.

в) сложена имена јављају се у корпусу као два типа:

1) тип вук- + друга творбена основа (са спојним вокалом / без спојног вокала)

Вукобрат, Вукољуб, Вукман, Вукобој, Вукобрад, Вуковоје, Вукобаша, Вукосад, Вукосан, Вукозеб, Вуколек, Вукорад, Вучикоса, Вучикапа, Вукосин, Вугдраг, Вукослав, Вучислав, Вукотеча, Вукослава, Вучедолац, Вукојез, Вукомор, Вукород, Вуковатра, Вукекија, Вукогоје, Вукогреб, Вукокас, Вукобоже, Вукогај, Вукобран, Вукодим, Вукоход, Вукоказ, Вукимир, Вукобат, Вукомер, Вукобор, Вуконад, Вукосав, Вукделија, Вукомиље, Вудрагина, Вукониз, Вукомир, Вукобрз, Вукопија, Вукопеча, Вузман, Вукодиље, Вукобрко, Вучемило, Вуковуја, Вукобије, Вукоглав, Вукодраж, Вуимир, Вукамен, Вукодаје, Вуковод, Вукодух, Вукостреш, Вукодав, Вуколиш, Вукмирица, Вуиџара, Вучимир, Вујоман, Вукоман, Вучидања, Вуколов, Вучидар, Вукосал, Вукаган, Вукодер.

Забележено је 76 имена овог типа која можемо поделити у две групе:

a) стварна властита имена типа Вукман, Вукоман, Вукосав и

б) измишљена имена изузетне експресивности типа Вукобран, Вукопија, Вукоглав, Вукодиље, Вукониз, Вукостреш и сл. где се јасно уочава пишчево поигравање и потврђује креативност. 
С творбеног аспекта поједина имена се могу анализирати као примери комбиноване творбе са нултим суфиксом као што су: Вукобран, Вукорад, Вукоход и сл. где имамо окрњене глаголске основе у другом делу творенице. Како је централна лексема вук објединили смо их према позицији овог форманта у твореници, па се шире посматрано могу све обједити као сложенице, али се неспорно ради о примерима комбиноване творбе. Пошто има и примера где је друга основа непрозирна (нпр. Вукодиље, Вуковуја, Вуконад и сл.), одлучили смо се да их анализирамо обједињено према положају централне лексеме.

2) тип творбена основа + вук- (са спојним вокалом / без спојног вокала)

Алавук, Бадивук, Близивук, Братовук, Безвук, Вадивук, Вативук, Вишевук, Головук, Гледовук, Живовук, Кадивук, Маливук, Миовук, Мировук, Мрковук, Млативук, Пуштивук, Првовук, Паравук, Паливук, Ставучан, Сватовук, Скочивук, Самовук, Смичивук, Стоивук, Станивук, Стршивук, Стриживук, Световук, Суривук, Тројевук, Хадивук, Хаџивук, Цватовук.

Екцерпирано је 36 имена овог типа. Занимљиво је да нема понављања лексема са истом творбеном основом у првом делу творенице. Најбројније су императивне сложенице (18) типа Млативук, Паливук, Пуштивук, Скочивук, Стриживук, Станивук и сл. Неке од њих су само условно императивне пошто су онеобичајени спојеви па чисто формално подсећају на императивне сложенице (нпр. Бадивук, Хадивук, Хацивук и сл.). Остале су, већином, настале помоћу спојног вокала (Гледовук, Головук, Првовук, Самовук, Сватовук и сл.).

2.7.2. Презимена се јављају у мањем броју од имена (укупно 19) и сва су потврђена у српском језику за разликуод 
имена која су већим делом лексичке творевине самог писца, а не имена у српском језику, те су изузетно стилогена.

Вученић, Вуковић, Вујовић, Вуловић, Вучковић, Вушовић, Вучинић, Вукотић, Вујачић, Вуканић, Вуичић, Бјеловук, Вјеровук, Вулин, Вукајлија, Вученов, Вуклишчић, Вучић, Вукић.

Неспорно су презимена лексеме на -uћ (14), презимена Вулин, Вукајлија и Вученов, док се два презимена са лексемом -вук у другом делу творенице могу двојако тумачити - или као презимена или као стилогена имена - Бјеловук ${ }^{17}$, Вјеровук.

3. На основу проведене анализе уочавамо изразито лексичко богатство које је већ посведочено у литератури за целокупно Бећковићево стваралаштво. И само на основу две изабране поеме уочено је мноштво стилематичних лексема што потврђује јасан песников циљ да се поиграва са језиком и ствара у језику. Поред изразите творбене продуктивности запажа се и семантичка продуктивност која је постигнута спајањем необичних лексема у једну као и спајањем семантички неспојивих лексема. Корпус је садржао око 450 лексема од чега су већином именице и само три сложена придева која су била изразито стилогена. Највише је деривата (око 200), а затим сложеница (око 150). Најбројније су лексеме са основом вуку творбеној основи (преко 300) што је у вези са избором корпуса (поема Вучја тужбалица). Запажа се изразита творбена и семантичка креативност заснована на продуктивним творбеним моделима. Изузетак је шест лексема са непродуктивним творбеним моделом где имамо у резултату оказионализме (нпр. јапајајии, немаништеници, празнозбори и сл.). Постојање Речника уз поеме довољно

17 Презиме Бјеливук постоји, па отуда претпоставка да постоји и презиме Бјеловук. 
говори да се ради о лексички богатом корпусу и тиме нам је умногоме помогло у творбено-семантичкој анализи бројних лексема које су семантички непрозирне. Мешање дијалекатске лексике и творачких процеса резултирало је гомилањем стилематичне лексике која се намеће приликом читања и тера читаоца да открива нове речи и њихова значења. Овакав корпус отвара простора за бројне језичке и језичко-стилске анализе.

\section{ИЗВОР}

Бећковић 1983: Матија Бећковић, Поеме, Београд: Српска књижевна задруга, коло LXXVI књига 508.

\section{ЛИТЕРАТУРА}

Делић 2012: Јован Делић, Аутопоетички тренуци Матије Бећковића - језичка самосвијест, у: Зборник радова О песмама, поемама u поетици Матије Бећковића, Београд- Требиње: Институт за књижевност и уметност; Учитељски факултет Универзитета у Београду; Дучићеве вечери поезије, Требиње, 17-48.

Ђуровић 2016: Сања Ђуровић: Израда речника писаца као допринос познавању лексикона (на примеру прозе Видосава Стевановића), у: Наш језик XLVII/3-4, 49-61.

Ковачевић 1995: Милош Ковачевић, Антитетичка фигурација у поезији Матије Бећковића, у: Зборнику реферата са научног скупа Поетика Матије Бећковића, (приредили: Милош Вукићевић, Ново Вуковић, Милош Ковачевић), Никшић, 103-118.

Ковачевић 2013: Милош Ковачевић, Српски писии у озрачју стилистике, Београд: Филип Вишњић.

Ковачевић 2015: Милош Ковачевић, Стилистика и граматика стилских фигура, четврто битно допуњено издање, Јасен.

Милановић 2012: Александар Милановић, Иза језичке игре у 
Бећковићевој поеми „Ћераћемо се још”, у: Зборник радова $O$ песмама, поемама и поетиии Матије Бећковића, БеоградТребиње: Институт за књижевност и уметност; Учитељски факултет Универзитета у Београду; Дучићеве вечери поезије, Требиње, 351-378.

Радуловић $1999^{1}$ : Зорица Радуловић, О лексици Матије Бећковића, у: Стварате, 54, бр. 6/8, 596-605.

Радуловић 1999²: Зорица Радуловић, Лексичко-семантичка компонента творбених модела у дјелу Матије Бећковића, у: Четврти тингвистички скуп Бошковићеви дани, Подгорица: ЦАНУ, 152-160.

Радуловић 2012: Марко Радуловић, Искушење говора - пародија и парадокси Матије Бећковића, у: Зборник радова $O$ песмама, поемама и поетиии Матије Бећковића, БеоградТребиње: Институт за књижевност и уметност; Учитељски факултет Универзитета у Београду; Дучићеве вечери поезије, Требиње, 203-229.

PMC: Речник српскохрватскога књижевног језика, I- I, Нови Сад (I-III и Загреб), Матица српска (I-III и Матица хрватска), 1967-1978 [РСАНУ = PMC - MX 1-3 и РМС 4-6].

Сувајџић 2012: Бошко Сувајџић, Вук и камен - апелативни жанрови у поезији Матије Бећковића, у: Зборник радова $O$ песмама, поемама и поетиии Матије Бећковића, БеоградТребиње: Институт за књижевност и уметност; Учитељски факултет Универзитета у Београду; Дучићеве вечери поезије, Требиње, 123-158. 
Sanja Đurović

\section{STILEMATIC WORDS IN SELECTED POEMS BY MATIJA BECKOVIĆ}

In this paper we analyzed the examples of excercised stilematic lexemes from the third book of poems "Lele i kuku”(„Lelek mene” and „Vučja tuzbalica”).

The corpus contained about 450 lexemes, most of which were nouns. The most is the derivatives (about 200), then the compound (about 150). The most numerous are lexemes with the basis of "vuk-" on the basis of creation (over 300), which is related to the choice of the corpus (the poem „Vučja tuzbalica”).

Key words: semantic, wordformation, poem, Matija Beckovic 